\title{
Conciliação, disputa e residualidade: A reforma agrária no Brasil durante os governos do PT
}

\author{
Marcos Paulo Campos
}

\author{
PALAVRAS-CHAVE: reforma agrária, Brasil, PT, movimentos sociais \\ rurais.
}

\section{CLASSIFICAÇÃO JEL: N16, Q34, Q28, H41.}

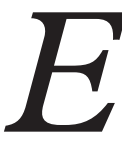

ste artigo trata da política de reforma agrária dos governos Lula da Silva e

Dilma Rousseff e analisa como os mandatos presidenciais do Partido dos Tra-

balhadores (PT) foram marcados pelo caráter residual da desconcentração de terras. O trabalho busca recompor sistematicamente os sentidos e as práticas do conflito politico entre governos petistas e movimentos sociais do campo com informações obtidas na análise do conteúdo de documentos partidários, eleitorais e governamentais, no acompanhamento sistemático de periódicos nacionais, na análise descritiva de dados quantitativos sobre ocupações de terras, disponibilizados pelo DATALUTA/UNESP e pela Comissão Pastoral da Terra (CPT), e na inserção etnográfica em eventos de protesto. Esses dados permitem perceber que a perspectiva conciliatória com a qual o PT ganhou as eleições de 2002 não se sustentou no exercício governativo devido a disputas intensas em torno da política agrorreformista que não evitaram o caráter residual da ação governamental no campo assumiu após a reeleição de Lula da Silva em 2006. 


\title{
Conciliation, contentious and residuality: Land reform in Brazil under the Workers' Party
}

\author{
KEYWORDS: land reform, Brazil, PT, agrarian movements.
}

\section{JEL CODES: N16, Q34, Q28, H41.}

his paper analyzes the land reform policy of Lula da Silva and Dilma Rouss-
eff governments and how the presidential mandates of Workers' Party (PT)
constituted a residual land reform in Brazil. The paper aims to systematically compose the meanings and practices of the political conflict between PT's governments and agrarian movements with sessions that replace data obtained from analysis of electoral and governmental documents, from systematically accompanying national journals, from descriptive analysis of quantitative data on land occupations, available by DATALUTA/UNESP and the Pastoral Land Commission (CPT), and from field observations in protest events. These data make it possible to realize that the conciliatory perspective wherewith the PT won the 2002 elections was not based on the government exercise during which contentious arose about agrarian reformism without, however, relieving it of the residual character it assumed after the re-election of Lula da Silva. 


\section{INTRODUÇÃO}

Este artigo analisa a disputa política em torno da reforma agrária no Brasil durante os governos nacionais do Partido dos Trabalhadores (PT) e busca compreender como se constituiu um reordenamento fundiário caracterizado pela baixa desconcentração de terras durante os mandatos presidenciais de Luiz Inácio Lula da Silva (2003-2010) e Dilma Rousseff (2011-2016). Nesse sentido, a análise aqui exposta busca recompor sistematicamente os sentidos do conflito político estruturante da reduzida distribuição de lotes agrários que marcou os governos nacionais petistas. A baixa desconcentração fundiária promovida pelos governos petistas é nomeada de agrorreformismo residual, sendo também compreendida como a configuração final de um processo precedido de intensas disputas dentro e fora das instituições políticas brasileiras. Essas disputas foram capazes de fragilizar tanto a elaboração programático-eleitoral inicial como a aliança partidária liderada pelo PT e forjada na perspectiva da conciliação de classes sociais.

Ariovaldo Umbelino de Oliveira (2010), Miguel Carter (2010), Timothy Power (2014), Esteban Iglesias (2011), André Singer (2012), Bernardo Mançano Fernandes (2013), José de Souza Martins (2011, 2016) e Anthony Pahnke (2018) compõem uma literatura crítica a respeito dos governos nacionais petistas em geral e de sua política de reforma agrária em particular. André Singer e Timothy Power preferem definir os governos nacionais petistas como recuos em relação ao programa histórico do PT, mas ainda assim os consideram como experiências progressistas na história brasileira recente. No plano da questão agrária, Ariovaldo Oliveira, José de Souza Martins e Bernardo Mançano Fernandes convergem na afirmação de que não houve desconcentração fundiária em larga escala durante os governos do PT no Brasil. Ariovaldo Oliveira sustenta que a obrigação constitucional de executar a política pública de reordenamento fundiário foi deixada de lado desde o primeiro mandato presidencial petista. $\mathrm{O}$ autor também critica o governo por não apresentar explicações públicas para o não cumprimento de metas do II Plano Nacional de Reforma Agrária (II PNRA) (Ministério do Desenvolvimento Agrário, 2003). Além disso, Ariovaldo Oliveira afirma que a ascensão de burocratas corruptos do Instituto Nacional de Colonização e Reforma Agrária (Incra), órgão executor da política agrária federal, assegurou a criação de instrumentos legais para regularizar a apropriação privada de terras públicas pelos grandes fazendeiros, sobretudo, na região amazônica. José de Souza Martins reconhece tanto a tendência latifundista, de longa data, no meio rural brasileiro, como o rebaixamento, conjuntural, do potencial conflitivo das organizações de luta no campo frente aos presidentes petistas. O sociólogo entende a possível calmaria dos conflitos por terra como a resultante de um manejo político, pois «o PT no poder empenhou-se ativa e detalhadamente numa política de conciliação dos contrários, amansando e enquadrando os belicosos, como fez com o MST [Movimento Sem Terra] (cuja agres- 
sividade decaiu no período)» (Martins, 2011: 10). Nesses termos, o sentido conciliatório da intervenção estatal no campo durante os governos nacionais petistas adquire maior relevo explicativo, bem como o efeito da política social do período que, para Martins, se tornou uma forma de inclusão dos empobrecidos num modelo institucional de conformismo político e apaziguamento de conflitos.

Bernardo Mançano Fernandes distancia-se das análises já apresentadas por reconhecer os governos nacionais do Partido dos Trabalhadores como a conjuntura política de um reordenamento parcial da concentração fundiária. O geógrafo entende os governos do presidente Lula da Silva como mandatos de enfrentamento tímido ao tema da desconcentração de terras. Os instrumentos de desapropriação, portanto, não tiveram centralidade na política de reforma agrária dos mandatos petistas. Isso fez com que o acesso à terra não implicasse em desconcentração fundiária no referido período. Bernardo Fernandes dirige sua crítica ao alcance da política agrária dos governos do PT cuja incapacidade de alterar a subordinação do agricultor familiar à agricultura empresarial ocorreu mesmo com a execução de importantes programas voltados à pequena e à média produção agrícola, nomeada de agricultura familiar. Dentre esses programas, destacam-se o Programa Nacional de Fortalecimento da Agricultura Familiar (Pronaf), o Programa de Aquisição de Alimentos (PAA), o Programa Nacional de Educação na Reforma Agrária (Pronera) e o Programa Nacional de Alimentação Escolar (PNAE). No entanto, Bernardo Fernandes considera que, ao invés de aquietadas, as organizações de luta no campo foram as responsáveis pelo reordenamento agrário, mesmo que limitado, ocorrido nos governos dos presidentes Lula da Silva e Dilma Rousseff.

Miguel Carter, Esteban Iglesias e Anthony Pahnke problematizam os governos nacionais do PT a partir das ações dos movimentos sociais e concluem que as intensas articulações entre Estado e sociedade civil organizada estão na base das políticas públicas democratizantes do período. Contudo, se houve democratização, isso não significa que os projetos de ampla transformação social, gestados pelos movimentos sociais brasileiros, tenham sido a única agenda dos governos nacionais petistas. Miguel Carter e Esteban Iglesias alertam para a institucionalização do diálogo político que pode frear as demandas dos movimentos sociais e impedir o avanço de suas reivindicações. Anthony Pahnke aponta que a estreita proximidade entre o MST e o governo do PT significa que o Movimento rompeu com a hostilidade inicial que experimentava na relação com as instituições governamentais e passou a utilizar estrategicamente de sua proximidade com o Estado em favor da ampliação de políticas públicas para os pobres do campo.

Como se pode perceber, a literatura especializada problematiza três temas ao tratar da reforma agrária nos governos nacionais petistas, sendo esses: o sentido do agrorrefor- 
mismo governamental, as formas de ação dos movimentos sociais rurais nesse contexto e, por fim, os resultados em desconcentração fundiária e desenvolvimento no campo. Essas polêmicas dão corpo às três sessões seguintes deste artigo que recuperam dados obtidos a partir de variados métodos de pesquisa. Para acessar o sentido da política agrária dos governos do PT, as informações foram buscadas na análise do conteúdo de documentos partidários, eleitorais e governamentais e no acompanhamento sistemático de revistas e jornais de circulação nacional com destaque para o jornal Folha de São Paulo. O entendimento sobre a ação dos movimentos sociais no campo privilegia a análise descritiva de dados quantitativos sobre ocupações de terras, disponibilizados pelo DATALUTA/UNESP e pela Comissão Pastoral da Terra (CPT) em seu relatório anual «Conflitos no Campo Brasil», mas também se utilizou da inserção etnográfica em eventos de protesto e de fontes secundárias. A análise sobre a desconcentração fundiária e o desenvolvimento agrário durante os governos nacionais petistas valeu-se dos métodos precedentes em cotejo com o posicionamento de analistas de conjuntura e da questão agrária.

\section{A REFORMA AGRÁRIA E O PARTIDO DOS TRABALHADORES}

A chegada do Partido dos Trabalhadores ao poder, com a vitória de Lula da Silva em sua quarta disputa presidencial, é um fenômeno com muitos significados. Para André Singer, «2002 pode ser o marco inicial de fase prolongada no Brasil, como aconteceu nos E.U.A. com a ascensão de Franklin Delano Roosevelt. Em 1932, nos E.U.A., assim como em 2002 no Brasil, numa típica eleição de alternância, forma-se nova maioria» (Singer, 2012: 14). Isso porque, tendo-se constituído no contexto da redemocratização com a articulação entre movimentos sociais, novo sindicalismo, setores progressistas da Igreja Católica e de outras denominações cristãs, militantes de esquerda, profissionais liberais e intelectuais, o PT encarnava amplas expectativas em torno de um projeto político modernizador e igualitário para o país (Secco, 2011). Mais do que isso, Eli Diniz assegura que a vitória petista participa de «um contexto favorável à retomada do debate sobre estratégias alternativas de desenvolvimento na América Latina em geral e no Brasil em particular» (Diniz, 2011: 493).

As expectativas em torno da vitória petista concorreram para certa percepção política e intelectual de que mudanças significativas entrariam na agenda governativa, dentre elas, a reforma agrária. Contudo, a proposta de política para o meio rural apresentada pelo PT em sua quarta campanha presidencial diferiu bastante das apresentadas em outras eleições. Em 1989, por exemplo, na primeira eleição presidencial direta depois da Ditadura Militar, a campanha do Partido dos Trabalhadores apresentou um programa de governo comprometido com amplas mudanças na sociedade brasileira. As políticas públicas para o campo estavam em uma sessão particular do referido documento eleitoral, compondo 
um caderno específico com o subtítulo "Questão Agrária». Nessa sessão, a questão fundiária é reconhecida como parte do conflito social distributivo em seus nexos com a democracia e o desenvolvimento. $\mathrm{O}$ documento assume a perspectiva clássica da reforma agrária como medida estrutural de incentivo ao desenvolvimento capitalista capaz de incluir no contrato social moderno as populações que não residem nas cidades nem trabalham na indústria ou nos serviços. Nesse sentido, convém repor que a intervenção deliberada do Estado nas bases do setor agropecuário da economia em busca de modificar a estrutura de propriedade agrária de uma região ou de um país na direção de uma distribuição mais equânime da terra e da renda agrícola é o entendimento mais consensual para o termo reforma agrária (Veiga, 1991). Isto é, no contexto da modernidade, a reforma agrária é uma medida fundamental aos processos de desenvolvimento tipicamente capitalistas (Martins, 1994). E mais, José Eli da Veiga (1994) aponta que se espera da reforma agrária um efeito produtivo na oferta de alimentos e um efeito distributivo na renda com o barateamento da oferta de alimentos. Para o autor,

"com base nos efeitos econômicos das reformas agrárias realizadas no século xx, o que se podia esperar desse tipo de programa era exatamente esses dois tipos de impacto: o produtivo e o distributivo. $\mathrm{O}$ aumento da produção agrícola tinha sido uma característica constante das reformas realizadas. Até a boliviana, de 1953, sempre usada pelos anti-reformistas como exemplo de desastre econômico teve, na realidade, resultado positivo na expansão da oferta, conforme indicam as avaliações feitas, no final dos anos 70, pelo Banco Mundial» (Veiga, 1994: 69).

Além do duplo efeito apontado na citação acima, José de Souza Martins (2000) acrescenta que, embora nem sempre agrade aos capitalistas de seu tempo, a reforma agrária favorece o desenvolvimento do capitalismo de tipo industrial e moderno por dirigir às fábricas o investimento que ficaria imobilizado em terras. Não por acaso, a desconcentração fundiária, em distintos contornos, teve lugar na história de, praticamente, todos os países centrais do capitalismo (Hobsbawn, 1983). No caso brasileiro, o histórico de industrialização dirigida pelos grandes proprietários de terra particulariza o processo de desenvolvimento -por não contar com a disputa entre o segmento agrário e o segmento fabril da burguesia que ocorreu em outras nacionalidades, por exemplo, os E.U.A.- e constitui forte entrave à realização de um programa de reforma agrária com amplo alcance porque o agrorreformismo não integra os interesses de nenhuma fração da burguesia nacional. Ao contrário, o recrudescimento da grande propriedade, por mecanismos legais e ilegais, tem sido parte da estratégia de reprodução da elite econômica brasileira.

As formulações do programa de governo petista, em 1989, não necessariamente encontraram ressonância nas propostas apresentadas pelo partido na década seguinte. Os 
anos da década de 1990 assistiram ao enfraquecimento da percepção sobre a reforma agrária como medida estrutural ao desenvolvimento e à democratização do país nos programas eleitorais petistas. Apesar disso, o tema agrorreformista seguiu compondo o núcleo das propostas da segunda candidatura presidencial de Lula da Silva. A eleição de 1994, que terminou com a vitória de Fernando Henrique Cardoso do Partido da SocialDemocracia Brasileira (PSDB), teve a reforma agrária apresentada pelo PT como saída para duas questões articuladas: a extrema pobreza e a demanda por alimentos das massas urbanas. A candidatura petista seguiu reconhecendo como problemática a permanência da concentração fundiária, mas a redistribuição de terras apareceu muito mais vinculada a seus efeitos sociais e econômicos, no plano da garantia de trabalho e de moradia para os pobres do campo e da ampliação da oferta de alimentos às cidades, do que como medida de democratização da propriedade e do acesso à terra capaz de enfraquecer o poder econômico e social dos grandes fazendeiros.

Os termos de enunciação do compromisso político do PT com a reforma agrária na eleição de 1998, finalizada com a reeleição de Fernando Henrique Cardoso (FHC), por sua vez, reproduzem e consolidam um deslocamento de sentido nos programas de governo do partido em que o reordenamento fundiário deixa de ser uma política pública para a revisão radical do direito de propriedade e mudança na estrutura de poder da sociedade brasileira, passando a ser apresentado como um programa social de enfrentamento à fome, garantia de moradia e geração de trabalho para os empobrecidos do campo. Isso significa a manutenção da orientação política em favor da redistribuição de terras, assumida pelo Partido dos Trabalhadores desde sua fundação, com a admissão da continuidade das grandes propriedades que sejam produtivas, pois a reforma agrária, desde a eleição anterior, não mais aparece como uma política de confronto com a concentração fundiária independente de sua produtividade. Ao final dos anos 1990, portanto, o reordenamento fundiário sofre uma profunda reconfiguração nos programas de governo petistas. A despeito disso, houve crescente demanda por terra expressa em ocupações de fazendas improdutivas, como demonstra o Gráfico 1 .

O aumento da demanda por terra ocorreu, segundo Guilherme Delgado (2010), concomitantemente à reorganização da chamada economia do agronegócio e isso ajuda a entender o denso conflito entre o capital e o trabalho no campo brasileiro durante a campanha eleitoral de 2002 na qual o programa de governo petista apresentou a proposta de conciliação entre reforma agrária e agricultura empresarial. Nesta altura, é importante dizer que o termo agronegócio é a nomeação empírica da parceria estratégica entre a concentração fundiária e a política de desenvolvimento no Brasil (Delgado, 2010). Essa parceria foi fortemente retomada na crise cambial brasileira de 1999, cenário de desmonte da paridade real/dólar e de reconstrução do marco de estruturação de uma nova estra- 
tégia de acumulação de capital no setor agrícola. Ao final dos anos 1990, assim como em outros momentos da história do país, o setor agrícola foi chamado a «gerar saldos de comércio exterior a qualquer custo, tendo em vista suprir o déficit de conta corrente» (Delgado, 2013: 63). O referido déficit ocorreu pela saída de recursos ocorrida com a desvalorização do real em relação ao dólar, conjugada ao fato de que a economia nacional importa produtos de alto valor agregado.

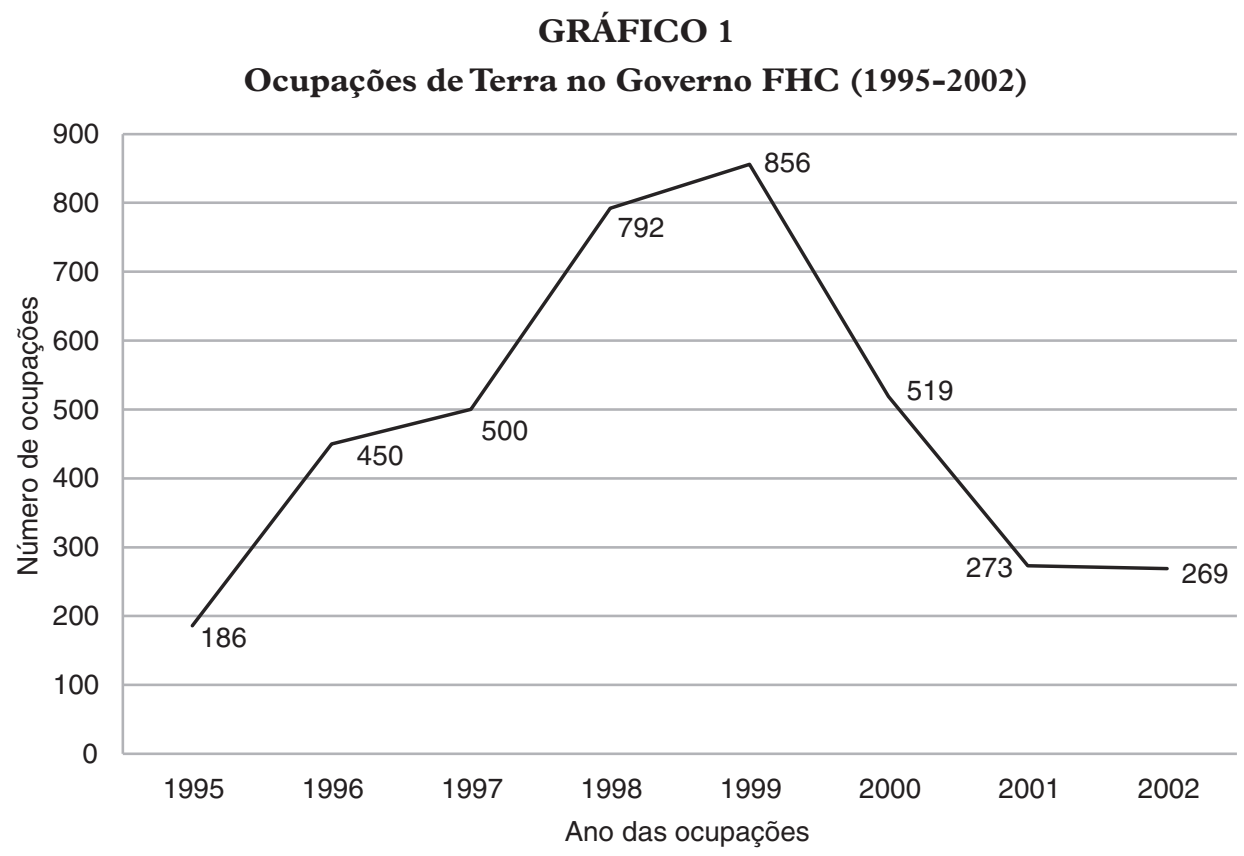

Fonte: DATALUTA.

As mudanças analisadas por Guilherme Delgado tiveram fortes implicações para a defesa política de um programa de reforma agrária, pois a grande propriedade mecanizada, com tecnologia intensiva de produção e voltada ao mercado externo, refez sua importância para as contas públicas e para o conjunto da economia nacional. Para Vitor Acselrad, após longo período de preocupações nacionais com a indústria de transformação, a agropecuária empresarial «recuperou sua posição estratégica no que se refere às exportações e ao equilíbrio das contas externas, sendo ainda responsável por parcela do recente êxito no combate à inflação» (Acselrad, 2012: 4). Essa renovada importância da grande propriedade agroexportadora deve ser considerada para pensar o contexto de apresentação do programa de governo da quarta candidatura presidencial petista. Se, desde 1989, as campanhas lideradas pelo PT afirmavam tanto a possibilidade de enfrentar o latifúndio em favor da industrialização, quanto o desaquecimento econômico da produção agrícola, 
em 2002, a candidatura petista ao governo federal teria que, necessariamente, enfrentar o papel da agropecuária de exportação como o setor mais dinâmico da economia nacional. E mais, isso teria que ser feito considerando o histórico compromisso do PT com a reforma agrária e o apoio político e eleitoral dos movimentos sociais e sindicais do campo ao partido, renovado nos três pleitos presidenciais anteriores. Não por acaso, o programa de governo da quarta candidatura presidencial petista adquiriu um sentido oposto às elaborações programáticas dos anos 1990 e passou a reconhecer o vigor econômico $\mathrm{e}$ social da produção agropecuária nacional. Se, em 1998, o caderno de propostas para a agricultura, produzido no contexto de forte unidade da esquerda brasileira, afirmou o enfraquecimento do setor primário do país, em 2002, a política agrária da candidatura presidencial do PT, exercitando um profundo deslocamento de sentido, admitiu o reposicionamento nacional do agronegócio. Essas redefinições programáticas ocorreram em consonância com outras mudanças da candidatura petista. A aliança partidária foi redefinida de forma substantiva, acolhendo setores do grande capital. $\mathrm{O}$ senador pelo Partido Liberal (PL) e empresário mineiro do ramo têxtil, José Alencar, foi escolhido para a vaga de vice-presidente na chapa liderada por Lula da Silva. A composição, portanto, expressava uma aliança entre empresários e trabalhadores, defendida pelo candidato do PT na campanha eleitoral. Tudo isso se somou ao apoio crescente e explícito de diversos setores do empresariado, inclusive, o setor agroexportador.

A redefinição de alianças e a incorporação de uma visão positiva sobre o papel da agropecuária de exportação na economia nacional impactaram a formulação sobre a política fundiária da candidatura petista em 2002. O documento com as propostas de política agrária da aliança encabeçado pelo PT, intitulado «Vida Digna no Campo», trazia os seguintes termos:

«A agricultura é um dos pilares fundamentais do nosso programa de governo, pois este setor é essencial para garantir a segurança alimentar de nosso povo, para a geração de empregos e de renda, para reduzir nossa dependência externa. Os dados falam por si mesmos, pois hoje a economia rural produz 100 milhões de toneladas de grãos, apesar da total insuficiência de incentivos; absorve para o trabalho $24 \%$ da população ocupada do país e gerou um superávit comercial de US $\$ 43,6$ bilhões, entre 1999 e 2001. [...] As políticas para agricultura familiar devem se desenvolver em paralelo àquelas orientadas para a agricultura empresarial. A agricultura empresarial gera empregos, renda e excedentes exportáveis. A agricultura familiar, além da produção de alimentos básicos de qualidade, também promove a ocupação soberana do nosso território; preserva tradições culturais do nosso país; mantém as pessoas em sua terra natal; pode contribuir na defesa de nosso meio-ambiente» (Coligação Lula Presidente, 2002: 3). 
A citação não deixa dúvidas sobre a incorporação do setor empresarial da agricultura como parte das atenções e da estratégia de desenvolvimento do futuro governo Lula da Silva. Longe de ser um setor inimigo ou combalido, o agronegócio passou a ser um setor chamado a uma estratégia de desenvolvimento que não parece poder prescindir de seus resultados em comércio exterior. Não é difícil compreender o deslocamento de sentido em favor de garantir a dinamização da agricultura empresarial para atendimento ao mercado externo, reiterando sua importância para obter o superávit primário com o qual o presidenciável do PT havia-se comprometido em carta pública e, ao mesmo tempo, assegurando o fortalecimento da agricultura familiar para o abastecimento do mercado interno e o combate à fome. Nesse sentido, o programa agrário reitera as intenções do documento público «Carta ao Povo Brasileiro», lançado pelo candidato petista em junho daquele ano eleitoral, no qual a superação do criticado fracasso econômico e social do governo FHC (1995-2002), entre outras estratégias, deveria buscar "valorizar o agronegócio e a agricultura familiar» (Silva, 2002: 3). O documento não reconhece ambiguidade em propor esse fortalecimento simultâneo e a reforma agrária é apontada como um meio para assegurar «a paz no campo».

A carta e o programa agrário de 2002 afirmam o reordenamento fundiário como uma política social, reiterando o sentido atribuído à redistribuição de terras desde a eleição anterior. Os documentos não apresentam a reforma agrária em oposição, mas sim em conciliação com a lógica da grande propriedade, reafirmando-a como uma política capaz de ser manejada no contexto de uma estratégia de desenvolvimento em que tanto o setor empresarial da agricultura como a pequena e a média produção tenham atenção e incentivo estatal. A reforma agrária como desconcentração fundiária em confronto com as grandes propriedades, preconizada por movimentos sociais e sindicais do campo e defendida outrora pelo PT, está fora de cogitação no programa de governo da quarta candidatura presidencial petista. A política de distribuição de terras e formação de assentamentos, contudo, seguiu como compromisso da candidatura de Lula da Silva em 2002, ladeada ao fortalecimento da agricultura de base familiar.

Em que pesem suas muitas distinções, as propostas para o meio rural do programa petista do início do século XXI mantêm relações com o sentido recorrente e hegemônico atribuído ao tema do reordenamento agrário nos programas de governo das candidaturas presidenciais petistas desde 1989. A dimensão econômica, por exemplo, preside a definição programática das políticas públicas para o meio rural, denegando assim as dimensões políticas da economia agrícola brasileira. No entanto, apesar de ter como objetivo precípuo o desenvolvimento econômico, a desconcentração de terras tem seu potencial de confronto com as grandes propriedades bastante reduzido, sendo posta lado a lado com as políticas de fomento à agricultura de exportação. A reforma agrária proposta 
pela quarta candidatura nacional petista em 2002 tem seu sentido reconfigurado a partir do possível governo de conciliação de classes para a realização lenta de reformas distributivistas sem confronto direto com o capital (Singer, 2012).

É importante ressaltar a admissão programática de que os desacertos da gestão do PSDB atingiram desigualmente os setores sociais no campo, prejudicando muito mais os trabalhadores rurais do que os grandes produtores. Ainda que a candidatura fale sobre o agronegócio não ter recebido bom tratamento da gestão pessedebista, mesmo não sendo bem isso que Guilherme Delgado (2010) demonstra, o programa agrário do PT em 2002 reconhece que a pequena e a média produção sofreram mais ainda com a desatenção estatal. Apesar da formulação conciliadora, a vitória de Lula da Silva elevou as atenções no campo da política agrorreformista governamental devido ao histórico de relacionamento entre o presidente, seu partido e os movimentos sociais do campo. A sessão a seguir trata das tensões, inflexões e impasses entre a demanda social por reforma agrária e o governo Lula da Silva.

\section{O AGRORREFORMISMO EM DISPUTA NO GOVERNO LULA DA SILVA}

Os debates sobre a composição ministerial capaz de executar o pacto político de conciliação de classes que constituiu a quarta candidatura presidencial de Lula da Silva assumiram o centro do debate público nacional logo após o pleito, sendo a escolha dos titulares para o Ministério do Desenvolvimento Agrário (MDA) e para o Ministério da Agricultura, Pecuária e Abastecimento (MAPA) marcada por tensões. O presidente eleito ainda não havia sido empossado quando Marilena Chaú, intelectual petista, e parlamentares do PT apresentaram publicamente críticas a alguns nomes cotados para compor o primeiro escalão do governo federal. Segundo o jornal Folha de São Paulo, a possível indicação de Roberto Rodrigues para o MAPA era contestada pelos petistas porque o futuro ministro defendia os interesses de grandes produtores rurais (Painel, 2002). Diante das críticas, Antonio Palocci, que coordenou o programa de governo de 2002 e logo foi anunciado como ministro da fazenda, argumentava a necessidade de compor a nova gestão com nomes bem relacionados aos setores produtivos. Nesse sentido, acabou sendo confirmada a indicação de Roberto Rodrigues para o MAPA. Esse engenheiro agrônomo formado pela Universidade de São Paulo (USP), com 60 anos à época, professor do Departamento de Economia Rural da Universidade Estadual Paulista (UNESP) e empresário da agricultura, afastou-se da presidência da Associação Brasileira do Agronegócio para assumir o cargo. O MDA, por sua vez, foi confiado a um petista, descrito pela revista Veja com o seguinte perfil: 
«Ex-líder do sindicato dos petroleiros, ex-deputado federal pelo PT e vice-governador do Rio Grande do Sul na gestão de Olívio Dutra, Rossetto, 42 anos, tem experiência política, credencial número 1 para ocupar um cargo explosivo como esse. Sua nomeação, no entanto, mexeu com os nervos dos produtores rurais. Motivo: para muitos fazendeiros, ficou a impressão de que Rossetto fala e age como se defendesse interesses dos sem-terra» (Secco, 2003: 9).

A citação acima e os dados do parágrafo anterior apontam que a habilidade para negociações e a vinculação orgânica com as organizações de representação política seja dos grandes produtores seja dos trabalhadores rurais foram critérios fundamentais nas indicações dos titulares para os dois principais ministérios da pauta agrária. E mais, as nomeações provocaram uma reação política semelhante e entrecruzada por parte das forças sociais envoltas nessa disputa política. Os agroexportadores viram com bons olhos a presença de um líder empresarial da grande agricultura na direção do ministério cujos programas atendem às demandas da agropecuária de exportação e criticaram a nomeação de Miguel Rossetto, aliado dos setores adversários à grande agricultura, para o MDA. Essa nomeação, por sua vez, foi bem recebida pelas frentes de luta no campo enquanto a confirmação de Roberto Rodrigues para o MAPA provocou as críticas já citadas.

Como se pode perceber, as primeiras nomeações do governo petista foram recebidas com «decepção e esperança num mesmo movimento» (Singer, 2012: 9). Isso, no entanto, não se restringiu às primeiras decisões. Na verdade, o ir-e-vir permanente de conflitos e acordos entre o governo Lula da Silva e os agentes sociais do agronegócio e da reforma agrária, tendo os referidos ministérios como polos institucionais dessa disputa política, marcou o primeiro mandato presidencial do Partido dos Trabalhadores. A arbitragem dessa disputa no interior do governo é considerada por LuizWerneckVianna (2007) como a tradução em prática política da composição pluriclassista própria à experiência governativa nacional petista, qualificada pelo analista como uma espécie de "Estado de compromisso» no qual os antagonismos e os conflitos sociais passam a ser orquestrados de dentro do ambiente político-institucional.

Retomando a entrevista do ministro do MDA à revista Veja (2003), é possível compreender o conjunto das respostas de Miguel Rossetto como certo "programa prático» para o MDA com as seguintes direções:

a) Preferência por um discurso público de não criminalização das formas de luta dos movimentos sociais rurais com reconhecimento da ocupação de terras improdutivas como mecanismo legítimo para a apresentação da demanda social por reforma agrária. 
b) Enfraquecimento dos instrumentos jurídicos e administrativos de contenção das ocupações de terras.

c) Composição da burocracia estatal de confiança (Incra e MDA) por meio da nomeação de membros dos movimentos sociais e sindicais do campo.

d) Realização da reforma agrária com baixo custo para o orçamento da União a partir do arcabouço legal já existente.

e) Execução de políticas públicas para dinamizar economicamente as áreas reformadas com investimentos em infraestrutura e produtividade, visando integrar à economia nacional as pequenas e médias propriedades agrícolas.

A execução do programa prático delineado por Miguel Rossetto teve que lidar com o agravamento das tensões no campo, ocorrido ainda no primeiro ano da gestão petista, com evidente aumento da letalidade nos conflitos por terra. Segundo a CPT, em 2003, houve 71 assassinatos de líderes da luta pela terra, tendo sido 43 no ano anterior. Esse aumento de $64 \%$ das mortes nos conflitos agrários provocou intensos debates entre os membros do governo nos quais fortes divergências foram explicitadas. Um exemplo disso são as declarações a respeito dos confrontos entre o MST e os seguranças armados das propriedades rurais. O ministro da Agricultura, Roberto Rodrigues, ao ser interpelado se a forma adequada para a defesa das grandes propriedades seria a contratação de milícias armadas, respondeu: «Qual é a outra maneira que você acha?» (Silveira, 2003: A4). Miguel Rossetto, preferindo um discurso de não criminalização dos movimentos sociais rurais, declarou que as milícias eram intoleráveis e que o governo iria eliminar qualquer tipo de ação nesse sentido. O então ministro da Justiça, Márcio Thomaz Bastos, também reiterou que a posição do governo era não aceitar nenhuma ação fora da legalidade. Posteriormente, Roberto Rodrigues procurou a imprensa para esclarecer que sua primeira declaração sobre o assunto foi um "escorregão» e que todos os integrantes do governo defendiam os limites legais.

Na perspectiva de redefinir os instrumentos jurídicos de cerceamento das ocupações de terra, em junho de 2003, o procurador-geral do Incra, Carlos Frederico Marés de Souza Filho, fixou o padrão de interpretação da Medida Provisória (MP) 2.183/2001, publicada no governo FHC (com validade de 120 dias até ser ratificada pelo Congresso Nacional) e conhecida como MP Anti-invasão. A interpretação do procurador enfraqueceu a aplicabilidade da referida medida provisória, apontando a possibilidade de vistoriar terras invadidas nos seguintes casos: quando a invasão ocorresse em parte pequena da propriedade sem impedimento à avaliação do cumprimento da função social do imóvel; 
quando a propriedade fosse constituída por diversas matrículas, pois cada uma seria analisada separadamente; quando o proprietário concordasse com a vistoria das áreas invadidas; nos casos em que a invasão ocorresse depois da vistoria; nas terras invadidas há mais de cinco anos e nas terras adquiridas pelo governo em operação comercial convencional. Essa interpretação foi questionada pelas elites agrárias e seus representantes no parlamento, inclusive entidades de produtores rurais entraram na justiça contra o presidente Lula da Silva e seus ministros por considerar a nova interpretação como uma agressão ao direito de propriedade.

Três semanas depois de uma reunião com o MST, ocorrida no início do mês de julho de 2003, quando ficou acordado a elaboração de um novo plano nacional de reforma agrária, já que o primeiro e único datava do governo Sarney (1985-1990), o presidente Lula da Silva recebeu lideranças empresariais do setor agropecuário, exceto da União Democrática Ruralista (UDR) que exigiu um encontro particular e não o teve. Nessa ocasião, o presidente afirmou: «o governo não fará nada fora da legalidade e não permitirá ilegalidade nem de um lado nem do outro porque o governo tem que exigir um processo de legalidade e de ordem jurídica» (Dualibi, 2003: A7). Essa fala corrobora os argumentos do ministro Miguel Rossetto e confirma o direcionamento da gestão petista em fazer a reforma agrária por meio da legislação já disponível, compreendendo o arcabouço legal das desapropriações com indenização aos fazendeiros como a referência para praticar o atendimento simultâneo tanto às agendas dos líderes da agricultura empresarial como às demandas das organizações de luta pela reforma agrária.

A discussão sobre as questões jurídicas que perpassam o processo de reordenamento agrário permeia constantemente a conjuntura política analisada. A bancada federal do PT, por exemplo, no contexto inicial do governo Lula da Silva, chegou a divulgar uma nota em que manifestava total solidariedade ao MST e apontava setores do judiciário em estreitas relações com o mais atrasado meio rural como responsáveis pelo agravamento das tensões no campo. A nota referia-se aos juízes que deram ordem de prisão a líderes semterra e ao próprio Supremo Tribunal Federal que anulou a primeira desapropriação de grande fazenda do governo Lula da Silva, feita no Rio Grande do Sul. Esse debate sobre as interferências do poder judiciário na questão agrária, entretanto, não superou a discussão pública sobre o tempo de realização da desconcentração fundiária que continuou sendo o ponto de maior tensão entre o governo e os líderes de movimentos rurais.

Em meados de 2003, o ministro da Secretaria-Geral da Presidência, Luiz Dulci, afirmou haver recursos disponíveis para o assentamento de 10.000 famílias naquele ano. Entretanto, o governo havia se comprometido, na reunião com os sem-terra, a assentar 60.000 novas famílias. Segundo Dulci, o número apenas poderia aumentar se o estoque de ter- 
ras públicas crescesse. Para isso, o ministro Miguel Rossetto apresentou ao presidente Lula da Silva a possibilidade de declarar como terras de interesse da reforma agrária as glebas de propriedade de empresas públicas e das empresas de economia mista sob controle da União como Petrobrás e Banco do Brasil. No fim do primeiro ano do governo petista, ao apresentar o balanço das ações do MDA, Miguel Rossetto afirmou estar satisfeito com os resultados. Segundo ele, foram assentadas mais de 34.000 famílias, os programas estavam melhor definidos para o ano seguinte e havia maior capacidade institucional para induzir a criação de dois milhões de empregos no campo. $\mathrm{O}$ ministro atribuiu às restrições orçamentárias e fiscais o não cumprimento do acordo de assentar 60.000 famílias.

O não cumprimento do acordo com o MST e a elaboração do II Plano Nacional de Reforma Agrária ocorreram num contexto de elevada tensão com os movimentos sociais do campo. Desde o início do mandato petista, as forças sociais organizadas e diretamente relacionadas ao mundo agrário estiveram em estado, tácito ou explícito, de tensão política. Não somente a nomeação dos titulares do MDA e do MAPA, mas também as indicações para as superintendências do Incra nas unidades da federação foram perpassadas por questionamentos e até ocupações de sedes do Instituto como forma de assegurar que as nomeações fossem previamente discutidas com os movimentos sociais rurais. No entanto, o que acabou por surpreender as organizações de luta no campo foi, ainda no segundo semestre do primeiro ano de gestão petista, a mudança na presidência do Incra pela qual Marcelo Resende, indicado com aval de movimentos e sindicatos rurais, foi substituído por Rolf Hackbart, assessor da liderança do PT no Senado Federal e mais próximo da burocracia partidária e do ministro do desenvolvimento agrário.

Marcelo Resende, ao sair do Incra, divulgou uma carta em que afirmava não ter sido previamente informado de sua demissão. Ele disse não ter assumido o Instituto por veleidade pessoal ou como forma de fazer carreira política e que possuía fé inabalável tanto no compromisso do presidente Lula da Silva com as populações necessitadas do meio rural como na luta dos movimentos sociais rurais. O ministro Miguel Rossetto, por sua vez, reconheceu ao jornal Folha de São Paulo não haver nada de desabonador em relação ao trabalho de Marcelo Resende. No entanto, o chefe da pasta do desenvolvimento agrário admitiu que, com a troca de comando no Incra, buscava mais convergência entre a equipe responsável pela política pública para o campo no governo petista. Rolf Hackbart, ao ser empossado, afirmou que «a reforma agrária é parte do plano de desenvolvimento econômico e social deste país. Não é uma mera política social» (Folha de São Paulo, 03/09/03). Essa afirmação o aproxima da acepção defendida pelo ministro em sua entrevista à revista Veja, mas também pode ser uma evidência do conflito de perspectivas entre Rossetto e Resende com relação aos sentidos do reordenamento fundiário no qual o ministro situava-se no polo econômico-produtivo enquanto o ex-presidente do Insti- 
tuto estaria no polo de uma revisão ampla do direito à terra. Um mês após sua nomeação para o Incra, Hackbart admitiu que o governo havia assentado 12.830 mil famílias e que mais de 28.000 estavam na fila sem previsão de quando receberiam terra.

O cenário de compromissos frustrados pelo governo petista acabou sendo acompanhado pelas ocupações de grandes fazendas que se tornaram o repertório de ação (Tilly, 1978) mais praticado pelas organizações de luta no campo durante o primeiro ano do mandato do presidente Lula da Silva. Os dados da CPT apontam que cerca de $43 \%$ das ocupações do ano de 2003 ocorreram somente nos meses de maio, junho e julho. O presidente da Confederação Nacional dos Trabalhadores na Agricultura (CONTAG), Manuel dos Santos, em meados do primeiro ano do governo petista, chegou a afirmar: «não dá mais para a gente segurar os trabalhadores com um vamos aguardan' (Suwwan, 2003: A7). Nessa declaração, o dirigente da principal entidade do sindicalismo rural do país reafirmou o tempo de realização da reforma agrária como a questão central das tensões entre as organizações de trabalhadores do campo e o governo Lula da Silva. Esse tema dominou a marcha organizada pelo MST em novembro de 2003 entre as cidades de Goiânia e Brasília para pressionar o governo federal a lançar, ainda naquele ano, o novo plano de reforma agrária. Além de cerca de dois mil sem-terra, participaram também as demais entidades do Fórum Nacional pela Reforma Agrária e Justiça no Campo, CONTAG e CPT. José Genoíno, então presidente nacional do PT, participou do início da marcha e afirmou o compromisso do partido em apoiar a luta do Movimento. A bancada petista na Câmara dos Deputados reuniu-se com os manifestantes na chegada da marcha em Brasília. Na capital federal, as entidades promoveram, com apoio do MDA, a Conferência da Terra para discutir propostas do II Plano Nacional de Reforma Agrária.

Em novembro de 2003, a versão final do II PNRA apontou as seguintes metas a serem cumpridas até 2007: assentamento de 400.000 famílias, regularização fundiária de 500.000 famílias, atendimento de 150.000 famílias com o Crédito Fundiário, recuperação da capacidade produtiva e da viabilidade econômica dos atuais assentamentos, criação de 2.075.000 novos postos permanentes de trabalho no setor reformado, implementação do cadastramento georreferenciado do território nacional para regularização de 2,2 milhões de imóveis rurais, reconhecimento, demarcação e titulação de áreas de comunidades quilombolas, reassentamento dos ocupantes não índios de comunidades indígenas, promoção da igualdade de gênero na reforma agrária, garantia da assistência técnica, extensão rural, capacitação, crédito e políticas de comercialização para as áreas reformadas e universalização do direito à educação, à cultura e à seguridade social em todas as áreas reformadas. A vigência do II PNRA assegurou maior destinação de recursos para obtenção de terras, como se pode ver abaixo (cotação $\$ 1=\mathrm{R} \$ 2,90 \mathrm{em}$ set./03 e $\mathrm{R} \$ 1,73$ em set./10). 


\section{TABELA 1}

Despesas com obtenção de terras (R\$), 2003-2010

\begin{tabular}{cccc}
\hline Ano do exercício & Recursos autorizados & Recursos executados & Percentual de execução \\
\hline 2003 & 483.489 .997 & 331.497 .466 & $68,56 \%$ \\
2004 & 1.140 .254 .200 & 903.816 .412 & $79,26 \%$ \\
2005 & 1.486 .841 .520 & 1.344 .037 .479 & $90,40 \%$ \\
2006 & 1.450 .364 .151 & 1.308 .394 .925 & $90,21 \%$ \\
2007 & 1.501 .868 .252 & 1.353 .081 .812 & $90,09 \%$ \\
2008 & 1.471 .399 .738 & 695.260 .297 & $47,25 \%$ \\
2009 & 1.021 .550 .261 & 753.099 .569 & $73,72 \%$ \\
2010 & 1.042 .000 .000 & 503.671 .956 & $48,34 \%$ \\
\hline
\end{tabular}

Fonte: SIAFI/STN.

A meta de assentamentos apresentada inicialmente estava em um milhão de famílias, mas a versão final do Plano assumiu um compromisso mais modesto. A despeito disso, como se pode ver, o plano agrorreformista elevou o orçamento para compra e desapropriação de terras à casa do bilhão. E mais, além da elevação geral dos recursos, houve maior efetividade de sua aplicação. O máximo dessa efetividade está na execução em 90,4\% dos recursos liberados para a obtenção de terras em 2005, constituindo esse e o ano seguinte como recordes em efetivo uso dos recursos liberados mesmo que o maior valor aplicado encontre-se em 2007. Isso ocorreu num contexto em que a promoção de grandes mobilizações nacionais começou a tomar mais espaço na agenda dos movimentos sociais rurais.

O terceiro ano do governo petista, segundo Miguel Carter (2010), assistiu à maior marcha à capital federal já realizada pelo MST até então, reunindo 12.000 pessoas. Apesar das mobilizações sociais, do maior valor aplicado em aquisição de terras situar-se no ano seguinte à reeleição de Lula da Silva e dos dois anos finais do primeiro mandato petista serem aqueles que registram os maiores percentuais de execução orçamentária, a maior quantidade de famílias assentadas (127.506 em 2005 e 136.358 em 2006, segundo o Incra) e o maior número de áreas incorporadas ao programa de reforma agrária (mais de 31 milhões de hectares entre 2003 e 2006 de acordo com o Incra), ao longo do segundo mandato petista a tendência favorável ao agrorreformismo inverteu-se. Em seu lugar, uma trajetória descendente dos recursos liberados e executados para a política pública de desapropriação e compra de terras foi estabelecida. É possível dizer, portanto, que a agenda para a agricultura de base familiar constituiu-se como o centro do discurso e das políticas públicas de desenvolvimento agrário dos governos Lula da Silva, e também dos governos Dilma Rousseff, seguindo trajetória contrária à política de reordenamento fundiário. $\mathrm{O}$ gráfico 2 condensa as informações sobre os recursos destinados ao Programa 
Nacional de Fortalecimento da Agricultura Familiar (Pronaf) que, desde 1996, é a política pública federal responsável por financiar o manejo produtivo da pequena e média produção agrícola nacional (cotação $\$ 1=\mathrm{R} \$ 3,25$ em set./16).

\section{GRÁFICO 2}

\section{Recursos Federais Liberados no Pronaf entre 2003-2016 (em bilhões de reais)}

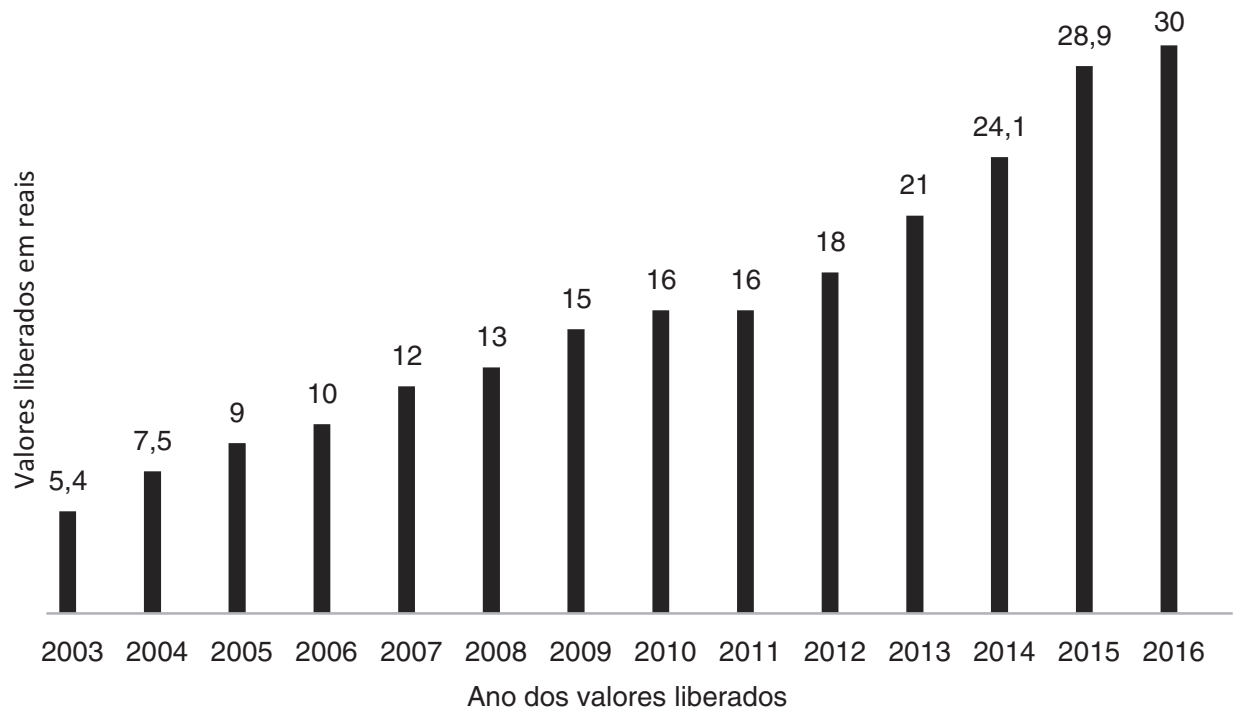

Fonte: MDA.

Se, para a aquisição de terras, os recursos tiveram elevação inicial seguida de queda constante, para o financiamento da pequena e da média produção, o aumento dos valores experimentou constância como demonstra o gráfico. Isso foi acompanhado da recomposição do quadro de funcionários do Incra com a realização de concursos que quase dobraram a quantidade de servidores da autarquia (Penna, 2015). No entanto, as iniciativas de melhoramento das capacidades estatais (Boschi, 2007) para a execução da política agrária não se deram sem conflitos. $\mathrm{O}$ fortalecimento das carreiras internas e das condições de ação institucional do Incra foram objeto de disputas nos governos petistas, inclusive, com a ocorrência de greves de servidores durante e em favor da obtenção de resultados positivos para a recomposição da massa laboral e do orçamento do Instituto. A redução dos recursos para obtenção de terras e a ampliação dos valores destinados à agricultura familiar, quando pensadas em conjunto, permitem qualificar a política dos governos nacionais petistas para o meio rural como um agrorreformismo residual, ou seja, uma prática política de intervenção estatal no campo pouco comprometida com a desconcentração fundiária e com foco na permanência e não no acesso à terra. 
É importante ressaltar o alerta que fazem Sérgio Sauer e George Mészáros (2016) a respeito da ampliação de outras políticas públicas para o campo que atenderam, principalmente, quem já estava na terra e não quem queria nela entrar. Nesse sentido, além do Pronaf, cabe destacar o Pronera, o PNAE e o PAA. Esse último foi criado pelo governo Lula da Silva para garantir mercado à pequena produção e colaborar com as iniciativas de segurança alimentar e combate à pobreza, tendo investimento crescente ao longo dos governos nacionais petistas como se pode ver abaixo.

\section{TABELA 2}

Programa de Aquisição de Alimentos (PAA), 2003-2012

\begin{tabular}{lccrc}
\hline Ano & $\begin{array}{c}\text { Recursos aplicados } \\
\text { (R\$ milhões) }\end{array}$ & $\begin{array}{c}\text { Agricultores familiares } \\
\text { participantes }\end{array}$ & $\begin{array}{c}\text { Pessoas } \\
\text { atendidas }\end{array}$ & $\begin{array}{c}\text { Alimentos } \\
\text { adquiridos (t) }\end{array}$ \\
\hline 2003 & 144,92 & 42.077 & 226.414 & 135.864 \\
2004 & 188,00 & 68.576 & 4.261 .462 & 339.925 \\
2005 & 333,06 & 87.292 & 6.450 .917 & 341.755 \\
2006 & 492,09 & 147.488 & 10.700 .997 & 466.337 \\
2007 & 461,06 & 138.900 & 14.512 .498 & 440.837 \\
2008 & 509,47 & 168.548 & 15.407 .850 & 403.155 \\
2009 & 591,03 & 137.185 & 13.028 .986 & 509.955 \\
2010 & 680,75 & 155.166 & 18.875 .174 & 462.429 \\
2011 & 667,33 & 160.011 & 20.976 .657 & 517.923 \\
2012 & 839,21 & 185.979 & 22.518 .088 & 529.034 \\
\hline
\end{tabular}

Fonte: MDS/SAGI/PAA-Data.

A tabela demonstra que o programa responsável por articular a pequena produção (oriunda de comunidades tradicionais, indígenas, pescadores, acampados, assentados da reforma agrária e agricultores familiares) e dirigi-la às populações em situação de insegurança alimentar e aos equipamentos públicos de alimentação e assistência social recebeu contínuo aporte de recursos sem decréscimos significativos no mesmo período em que a obtenção de terras descia aos menores patamares desde a redemocratização. $\mathrm{O}$ PNAE nasceu nos anos de 1950 e foi oficializado nos anos de 1980. No entanto, a partir de 2003, o programa passou a comprar mais intensamente os produtos da agricultura familiar, ampliando as expectativas e a comercialização dos pequenos produtores. Em 2009, uma mudança na lei do PNAE, impulsionada pelo governo petista, estabeleceu que $30 \%$ das compras governamentais para merenda escolar deveriam contemplar a agricultura familiar. O Pronera, por sua vez, tendo nascido em 1998 com seis cursos de escolarização para os assentamentos rurais, chegou a abrir 65 cursos em 2005. Como bem demonstra o relatório da II Pesquisa Nacional sobre a Educação na Reforma Agrária, realizada pela parceria entre o Instituto de Pesquisa Econômica Aplicada (IPEA) e o MDA 
e apresentada em 2015, os anos anteriores ao governo Lula da Silva trazem uma média de 22 novos cursos do programa por ano. Entre 2003 e 2010, a média do Pronera fica por volta de trinta novos cursos e com maior diversificação, deixando de ofertar apenas alfabetização e letramento e chegando a abertura de cursos de nível superior como graduações e especializações.

GRÁFICO 3

Ocupações de Terra nos Governos Nacionais Petistas (2003-2014)

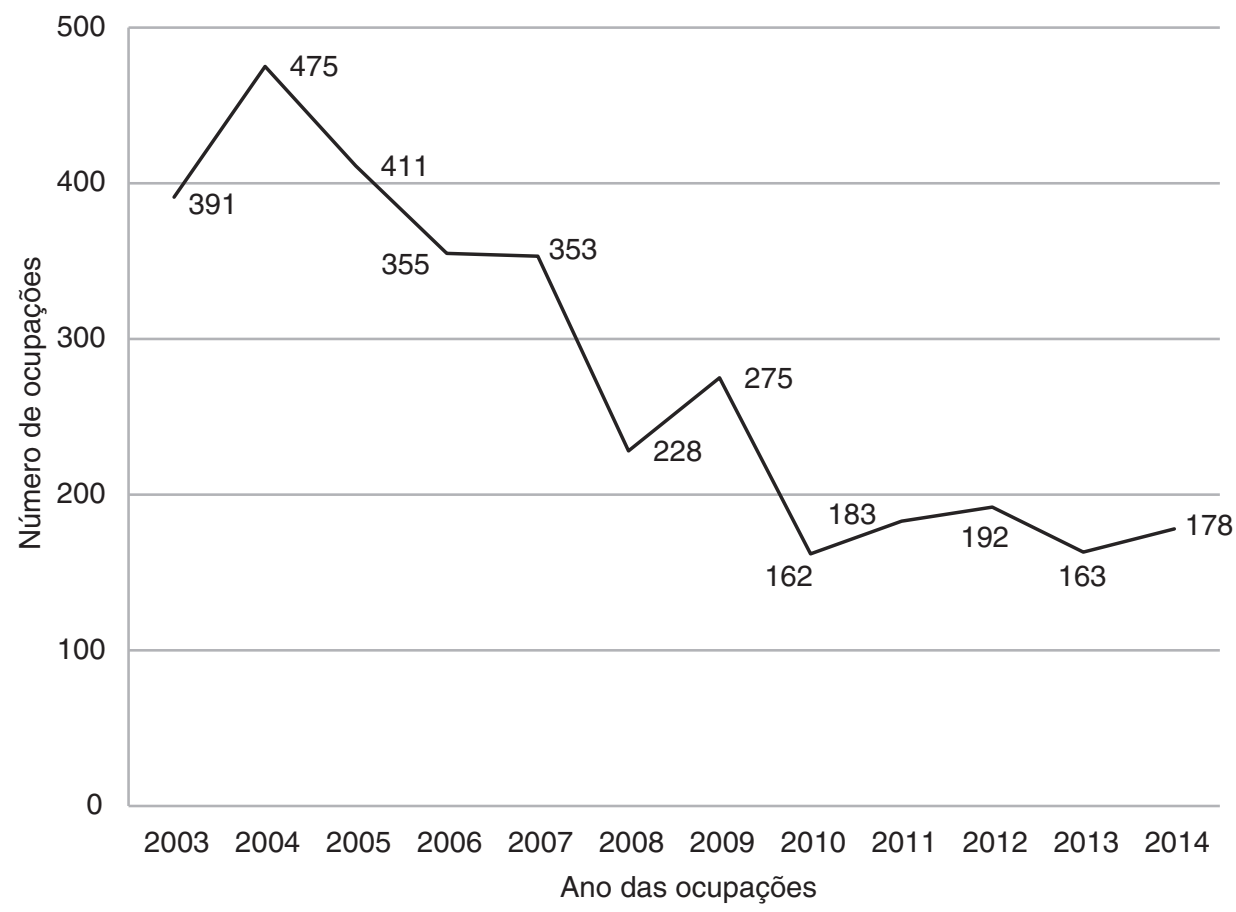

Fonte: CPT.

O influxo de recursos para a compra de terras com fins de reforma agrária não foi observado com parcimônia pelas organizações de luta no campo, apesar do aumento nos valores destinados para outras políticas agrárias. Os enfrentamentos ocorridos, principalmente, no contexto do primeiro mandato do presidente Lula da Silva fizeram com que a expectativa conciliatória das eleições de 2002 desse lugar a disputas intensas em torno dos sentidos do agrorreformismo nos governos do PT como se pode ver no Gráfico 3.

As tensões do primeiro mandato presidencial petista, portanto, não parecem confirmar, imediatamente, «a calmaria dos outrora belicosos» de que fala José de Souza Martins (2011). O gráfico apresenta bem a escalada de ocupações de terra no período, dei- 
xando nítido o avanço das tensões no campo durante o primeiro mandato petista. De acordo com a série histórica feita pela CPT desde 1985, o ano de 2004 registra o segundo maior número anual de ocupações de terra, perdendo apenas para o ano de 1999 quando houve mais de 850 ocupações. A despeito da comprovada agitação inicial, é inconteste que a intensidade das ações dos movimentos sociais ocorreu no contexto da execução do II PNRA e que a forma mais conflitiva de seu repertório de ação refluiu após o encerramento da vigência do Plano.

O que explica o evidente recuo das ocupações de terras ao longo dos governos petistas? Estariam certos aqueles que afirmam a desmobilização do MST e das demais frentes de luta no campo durante os governos do PT? Antes de responder a essas perguntas, é importante avaliar se seria adequado atribuir aos programas federais de transferência de renda, como fazem Ariovaldo Umbelino Oliveira e José de Souza Martins, uma forte razão para a redução das ocupações de terra. Para Ricardo Ceneviva e Ramon Araújo (2017), há analistas que valorizam demasiadamente o efeito dos programas federais para explicar a redução de ocupações. Com a utilização de metodologias e informações estatísticas, obtidas nas bases de dados da CPT e do Ministério do Desenvolvimento Social, os autores apontam que, para ter impacto relevante e desmobilizador nas ocupações de terra, o volume de recursos transferidos pelo Programa Bolsa Família (PBF) deveria ser maior. Segundo Ceneviva e Araújo, o efeito da principal variável explicativa, o PBF, sobre a variável dependente, o número total de ocupações de terra, não é tão relevante. Ou seja, "para se esperar a redução de somente uma ocupação seria necessário haver um aumento de $\mathrm{R} \$ 483,00$ nos gastos [anuais] per capita do PBF, o que equivale ao acréscimo de $R \$ 40,25$ mensais para cada habitante» (Ceneviva \& Araújo, 2017: 15). Evitando a resposta utilitarista para o questionamento sobre as mudanças no repertório de ação dos movimentos sociais rurais na conjuntura em foco, é possível considerar dois elementos combinados que resultam na redução das ocupações de terra, sendo eles: a preferência dos movimentos por mobilizações nacionais de protesto menos conflitivas com concentração na capital federal e a atenção governamental à parte das demandas das organizações de luta no campo, sobretudo, à agenda da agricultura familiar.

Sobre as formas de protesto, convém repor os argumentos de Rebecca Abers, Lizandra Serafim e Luciana Tatagiba (2014) a respeito da experimentação criativa de modelos de comunicação e negociação entre movimentos sociais e agentes estatais durante o governo Lula da Silva. A negociação com entes governamentais já era uma forma de ação comumente acionada pelos sem-terra e por assalariados rurais para o processamento das demandas dos trabalhadores do campo após a realização de ocupações e greves, como demonstram os trabalhos de Camila Penna (2015) e Lygia Sigaud (2005). Após a eleição do presidente Lula da Silva, a negociação assumiu uma centralidade não 
registrada anteriormente no repertório de ação dos movimentos sociais e sindicais rurais, sendo mobilizada constante e preferencialmente. Nessa conjuntura, movimentos sociais com reconhecida preferência por ações no limiar da lei, como o MST, acabaram por preferir mobilizar-se em conjunto com outras frentes de organização dos trabalhadores rurais em protestos nacionais na capital federal como forma de ampliar seu capital político nos diálogos com o poder público e na tentativa de influenciar diretamente as decisões da política agrária governamental. Dessa forma, as organizações de luta no campo dão razão a Luiz Werneck Vianna quando afirma que, diante da reunião de segmentos antagônicos que marcou a composição dos governos nacionais do PT, as forças em disputa pela orientação política desses governos agiram entendendo que «a melhor forma de vencer - ou não perder tudo- está em sua capacidade de arregimentar forças na sociedade civil» (Vianna, 2007: 53). A recorrência à negociação com o governo federal concomitante às demais práticas de contestação, portanto, marcou uma mudança nos repertórios de ação dos movimentos sociais e sindicais do campo durante os governos nacionais petistas.

\section{O GOVERNO DILMA ROUSSEFF E A CONSOLIDAÇÃO DO AGRORREFORMISMO RESIDUAL}

Eleita para dar continuidade ao governo petista, a presidenta Dilma Rousseff seguiu a tendência residual que o agrorreformismo assumiu desde o fim do II PNRA em 2007. A sucessora de Lula da Silva manteve tanto as limitações à política de redistribuição de terras como a ampliação dos recursos para a pequena e a média produção agrícola e para a produção agropecuária voltada à exportação. Se, nos programas de governo de $2002 \mathrm{e}$ 2006, o PT propôs a agricultura familiar como programa social e medida de geração de trabalho no campo, em 2010, o programa de governo da ex-ministra da Casa Civil apresentou a política agrícola fortemente relacionada à política industrial numa vinculação que lembra as concepções clássicas da questão agrária e os programas agrários petistas antes de 2002. Apesar dessa elaboração programática, o documento eleitoral evitou o tema do agrorreformismo como forma de transferência do dinamismo econômico para a indústria e preferiu indicar a intervenção governamental no campo nos moldes praticados pelo governo Lula da Silva. A eleição da presidenta, portanto, consolidou o agrorreformismo residual como prática de política agrária nos governos nacionais petistas. No último ano do governo Lula da Silva, $\mathrm{R} \$ 1,42$ bi foram liberados para operações de compra e desapropriação, sendo executados quase 48,3\% desse valor. Em 2011, Dilma Rousseff reduziu o recurso liberado para pouco mais de 994 milhões de reais, executando 33,2\% desse valor. No ano seguinte, o valor liberado decresceu $27 \%$, ficando em pouco mais de $R \$$ 717 milhões. Essa tendência decrescente de recursos impactou a política de assentamentos 
rurais, reduzindo a ampliação de áreas destinadas às famílias de trabalhadores demandantes de terra como mostra o gráfico 4.

\section{GRÁFICO 4}

Área em Hectares Incorporados ao Programa de Reforma Agrária nos Governos FHC (1995-2002) e Lula da Silva (2003-2010)

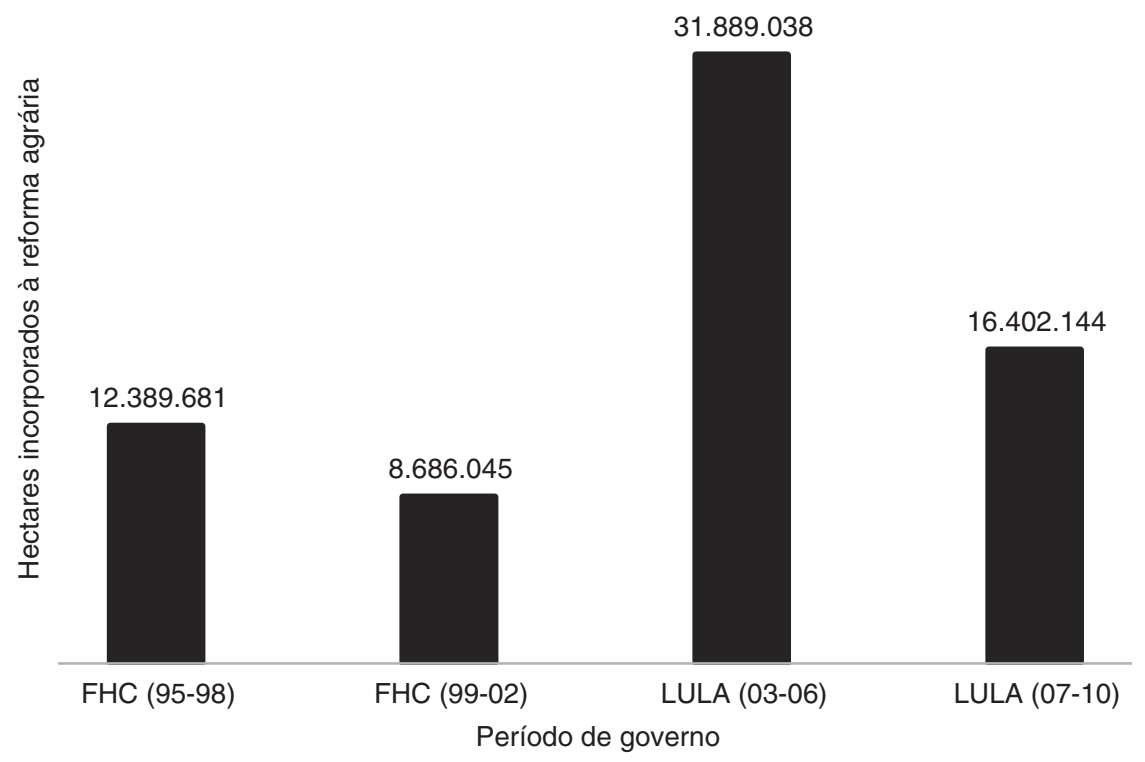

Fonte: Incra.

No cenário adverso apontado acima, os movimentos sociais e sindicais do campo organizaram o Encontro Unitário dos Trabalhadores, Trabalhadoras e Povos do Campo, das Águas e das Florestas. Esse evento foi realizado de 20 a 22 de agosto de 2012 por ampla rede de parcerias entre o MST, a CONTAG, a Federação Nacional dos Trabalhadores e Trabalhadoras na Agricultura Familiar FETRAF-Brasil (hoje chamada de CONTRAFBrasil), o Movimento dos Atingidos por Barragens (MAB) e o Movimento de Pequenos Agricultores (MPA), dentre outras organizações, e significou a maior reunião de frentes da luta social no campo desde o $1^{\circ}$ Congresso Camponês do Brasil que ocorreu em 1961. Uma das atividades mais importantes do Encontro Unitário foi uma marcha na capital federal com destino à Praça dos Três Poderes para pressionar o governo Dilma Rousseff em favor da reforma agrária, reivindicação número um do documento final do evento. Acompanhar a marcha permitiu ver a diversidade de populações do mundo rural (agricultores, quilombolas, pescadores, assentados e acampados) em uma ação coletiva de contestação que expressava fortemente a mudança no repertório de ação dos movimentos sociais e sindicais do campo durante os governos nacionais petistas quando foram reduzidas 
as ocupações de terras e ampliados os protestos de caráter nacional com coordenação colegiada. Ao chegar diante do Palácio do Planalto, onde despachava a chefe do executivo, a marcha abriu a faixa, abaixo fotografada, com a frase «Dilma, cadê a reforma agrária?» no intuito de tê-la lida pela presidenta.

\section{FOTO 1}

Marcha Final do Encontro Unitário dos Trabalhadores, Trabalhadoras e Povos do Campo, das Águas e das Florestas, Brasília, 22 de agosto de 2012

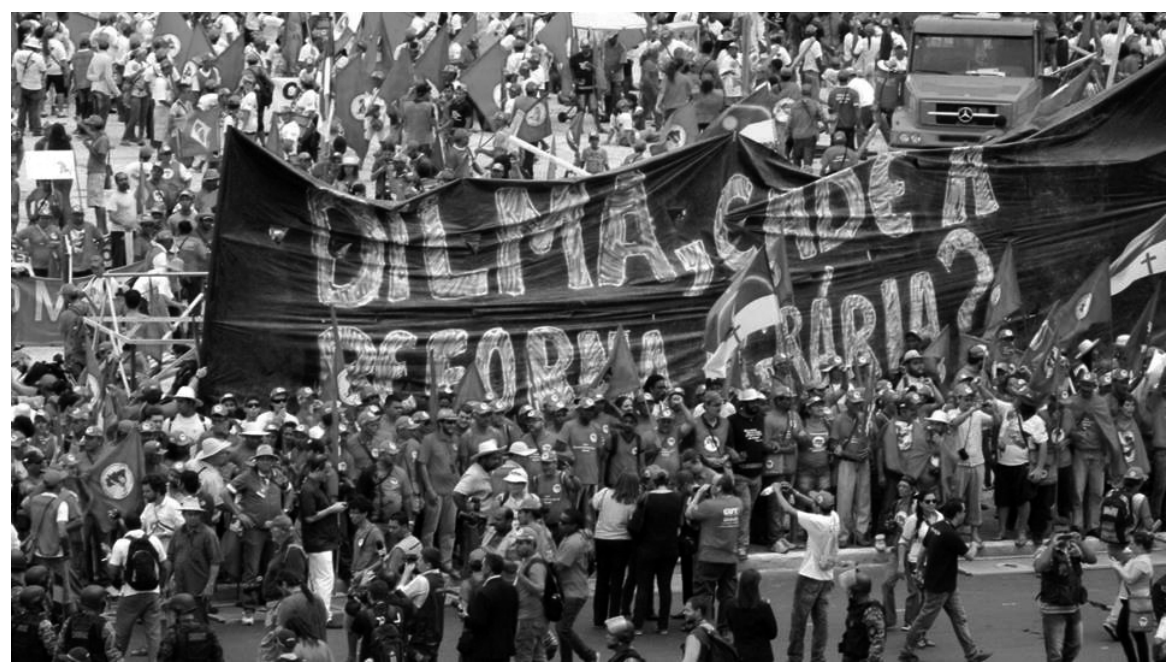

Fonte: arquivo pessoal.

Apesar das pressões e da reunião com ministros palacianos que ocorreu durante a marcha, o governo Dilma Rousseff não alterou muito os rumos de sua política agrária. Nos anos do governo Lula da Silva, apesar de ter recebido mais recursos e estruturação, a agricultura familiar nunca atingiu nem $15 \%$ do crédito rural do país. No mandato da sucessora petista, além dos empresários da agricultura terem ficado com mais de $85 \%$ do crédito rural do período, por dois anos consecutivos, 2012 e 2013, o agronegócio registrou uma aplicação superior aos valores inicialmente liberados para o Plano Agrícola e Pecuário (PAP) que reúne o financiamento da agricultura empresarial no país. Em 2012, conforme o MAPA, foram liberados $\mathrm{R} \$ 115,3$ bilhões para o PAP, mas o montante efetivamente aplicado teve 7,4 bilhões de reais acima do valor inicial. Isso também ocorreu com o Pronaf, mas os valores e a diferença entre montante liberado montante aplicado foram bem menores conforme a Tabela 3 a seguir.

Ao ser reeleita, a presidenta Dilma Rousseff chegou a nomear para o Ministério da Agricultura a senadora Kátia Abreu, líder da bancada ruralista e profundamente identi- 
ficada com a crítica aos movimentos sociais rurais e com as pautas de avanço do domínio agroempresarial sobre os territórios indígenas e quilombolas. O MDA foi confiado ao deputado federal Patrus Ananias (PT), bem relacionado às organizações da luta agrorreformista. Essas nomeações pareciam reacender a temperatura do debate agrário dentro do governo petista, mas não houve tempo suficiente para tanto já que o quarto mandato nacional consecutivo do PT foi interrompido por um processo de impeachment em 2016 ainda hoje alvo de questionamentos sobre sua legitimidade. No mês de abril do seu último ano de mandato, a presidenta assinou, em cerimônia bastante participada por movimentos sociais e sindicais do campo, 21 decretos de desapropriação para reforma agrária. E mais, Dilma Rousseff assinou quatro decretos de regularização de terras quilombolas. Essas ações faziam parte de uma agenda positiva do governo como forma de reafirmar a aliados fiéis os compromissos históricos numa conjuntura cada vez mais adversa.

TABELA 3

Comparação dos recursos aplicados para crédito rural

no Pronaf e no PAP (2003-2012)

\begin{tabular}{cccccc}
\hline Ano & $\begin{array}{c}\text { Recursos } \\
\text { aplicados no } \\
\text { Pronaf (R\$ bi) }\end{array}$ & $\begin{array}{c}\text { Recursos } \\
\text { aplicados no } \\
\text { PAP (R\$ bi) }\end{array}$ & $\begin{array}{c}\text { Total aplicado } \\
\text { em crédito rural } \\
\text { (PAP+Pronaf) }\end{array}$ & $\begin{array}{c}\text { Percentual do Pronaf } \\
\text { em relação ao total } \\
\text { aplicado }\end{array}$ & $\begin{array}{c}\text { Percentual do PAP } \\
\text { em relação ao } \\
\text { total aplicado }\end{array}$ \\
\hline 2003 & 3,5 & 35,2 & 38,7 & $9,00 \%$ & $91,00 \%$ \\
2004 & 4,6 & 41,9 & 46,5 & $10,00 \%$ & $90,00 \%$ \\
2005 & 6,4 & 42,6 & 49,0 & $13,00 \%$ & $87,00 \%$ \\
2006 & 7,1 & 46,0 & 53,1 & $13,00 \%$ & $87,00 \%$ \\
2007 & 8,1 & 65,9 & 74,0 & $11,00 \%$ & $89,00 \%$ \\
2008 & 10,4 & 64,9 & 75,3 & $14,00 \%$ & $86,00 \%$ \\
2009 & 12,6 & 86,8 & 99,4 & $12,00 \%$ & $88,00 \%$ \\
2010 & 13,3 & 94,5 & 107,8 & $12,00 \%$ & $88,00 \%$ \\
2011 & 15,3 & 93,5 & 108,8 & $14,06 \%$ & $85,94 \%$ \\
2012 & 18,6 & 122,7 & 141,3 & $13,16 \%$ & $86,84 \%$ \\
\hline
\end{tabular}

Fonte: MDA e MAPA

A despeito dos gestos finais de seu mandato, inegavelmente, a presidenta Dilma Rousseff consolidou a residualidade como a qualidade hegemônica da política de reforma agrária dos governos nacionais petistas. Houve, portanto, contínua redução de recursos para obtenção de terras e constituição de novos assentamentos rurais enquanto o programa de fortalecimento da agricultura familiar seguiu tendo maior atenção e investimento, mas sempre em desnível com os montantes destinados para a agricultura empresarial. A experiência governativa do PT encontrou na política para a agricultura familiar uma espé- 
cie de "caminho do meio» para não perder laços com as frentes de luta no campo e, ao mesmo tempo, não ferir os interesses dos empresários da agropecuária de exportação.

\section{CONSIDERAÇÕES FINAIS}

Ao reconhecer o caráter residual da política de reforma agrária dos governos nacionais petistas, este artigo buscou percebê-lo como o resultado de um conflito político em torno da definição dos rumos do agrorreformismo nos mandatos presidenciais liderados por Lula da Silva e Dilma Rousseff. Nesse sentido, o campo de forças sociais e mediação em que se colocavam mobilizações a favor ou contra a reforma agrária nessa conjuntura foi observado, sobretudo, naquilo que correspondiam às posições dos agentes do governo e dos movimentos sociais e sindicais do campo. Isso permitiu perceber que a elaboração programática com a qual o PT venceu as eleições de 2002 apontava para a conciliação entre as políticas para o agronegócio e para reforma agrária como forma de intervenção governamental no conflito agrário do país, mesmo que as expectativas, baseadas no histórico petista, indicassem um agrorreformismo forte.

Após a eleição, a proposição conciliatória petista viu crescer as disputas em torno do agrorreformismo tanto nas instituições políticas como no meio rural, sendo essa elevada temperatura o contexto de construção e aprovação do segundo plano nacional para o reordenamento fundiário. No entanto, a execução parcial do plano e sua não continuidade, somadas à ampliação de recursos para a agricultura familiar, constituiu um modelo de política pública para o campo que pode ser traduzido como agrorreformismo residual pelo qual se fortalecem programas governamentais para quem já está na terra e se atende reduzidamente a demanda de acesso à terra e constituição de novos assentamentos rurais. Não seria difícil entender que boa parte da dificuldade governamental em aumentar a quantidade de terras disponíveis aos trabalhadores rurais ocorreu em virtude da opção por priorizar a compra governamental de glebas para transformá-las em assentamentos rurais (Lerrer \& Carter, 2017). Isso evitou confrontos maiores com os grandes fazendeiros, conforme a lógica apaziguadora de conflitos dos governos nacionais petistas (Singer, 2012), num momento em que o Brasil aprofundou sua presença nas cadeias globais da soja, da carne, do milho e do frango e, consequentemente, viu o preço de suas terras agricultáveis subirem. Como demonstram Georges Flexor e Sérgio Pereira Leite (2017), entre os anos de 2010 e 2015, dependendo da região do país, o preço das terras subiu de $130 \%$ a $220 \%$. O custo orçamentário da opção governamental implicou, portanto, em baixo alcance de sua política de distribuição de terras mesmo quando houve alto volume de recursos nela empregados. 
No plano dos movimentos sociais do campo, a conjuntura em foco assistiu à mudança de seu repertório de ação em que as ações diretas de questionamento à concentração fundiária, ou seja, as ocupações de terra, decresceram em favor de mobilizações nacionais na capital federal, como marchas e atos unificados, pelos quais se buscou influenciar a política agrária governamental a atender às demandas dos trabalhadores rurais sem obter, contudo, a reivindicada desconcentração fundiária no Brasil. Outro elemento que colabora para o entendimento dessa redução das ocupações é a própria morosidade do programa federal de distribuição de terras que, por sua lentidão, não produz o efeito conhecido como espiral de ocupações (Loera, 2006) pelo qual a participação em ocupações de terra aumenta à medida que a resposta governamental é célere. A queda na quantidade de novos assentamentos a partir de 2006 acabou por desanimar a mobilização de demandantes por terra em ocupações. Essa dificuldade é admitida pelas organizações de luta no campo e compõe as razões para a mudança nas formas de ação dos movimentos sociais rurais no período. Isso tudo ocorreu num cenário em que houve afastamento político entre os governantes petistas e as organizações de luta no campo, como afirma Ribeiro Neto (2018), apesar do aumento de investimentos estatais em políticas públicas para a agricultura familiar. Esses investimentos devem ser bastante considerados no entendimento da não ruptura entre os governos do PT e os movimentos sociais rurais porque significaram a realização parcial da agenda de reivindicações das organizações dos trabalhadores do campo que seguiram na base de apoio ao governo Dilma até o impeachment de 2016 e marcharam junto aos petistas para a oposição aos presidentes Michel Temer e Jair Bolsonaro.

Conciliação, disputa e residualidade são os três momentos mais significativos das políticas públicas para o campo durante os governos nacionais do Partido dos Trabalhadores no Brasil. Essa constatação permite concluir que a reforma agrária residual e o fomento à agricultura familiar dos governos nacionais petistas, embora tenham resultados significativos em redução da pobreza e da extrema pobreza rural, não foram capazes de desmontar os níveis de subalternidade da pequena e média produção agrícola em relação ao poderoso setor agroexportador (Fernandes, 2013). O tema da desconcentração fundiária foi adiado e, considerando os sucessores Michel Temer e Jair Bolsonaro, mais do que nunca está fora da agenda governamental brasileira. Não se sabe até quando.

\section{AGRADECIMENTOS}

Manifesto aqui meus mais sinceros agradecimentos aos revisores de Historia Agraria pela leitura atenta e primorosas sugestões recebidas. 


\section{REFERÊNCIAS}

Abers, R., Serafim, L. \& Tatagiba, L. (2014). Changing Repertoires of State-Society Interaction Under Lula. In F. DE CASTRO, K. Koonings \& M. Wiesebron (Orgs.), Brazil Under the Workers' Party (pp. 36-61). Basingstoke: Palgrave Macmillan.

ACsElRAD, V. (2012). A economia política do agronegócio no Brasil: O legado desenvolvimentista no contexto da democratização com liberalização. Tese de doutorado. Rio de Janeiro: Universidade do Estado do Rio de Janeiro.

BoschI, R. R. (2007). Capacidades estatais, empresários e desenvolvimento no Brasil: Uma reflexão sobre a agenda pós-neoliberal. Revista do Serviço Público, (58), 71-92. Carter, M. (2010). The Landless Rural Workers Movement and Democracy in Brazil. Latin American Research Review, 45 (4), 186-217.

Ceneviva, R. \& ARAújo, R.T. (2017). Recrutamento para ações de alto custo/risco e programas de transferência condicionada de renda: $\mathrm{O}$ caso de conflitos por terra no Brasil. In Anais do $41^{\circ}$ Encontro Anual da ANPOCS, (pp. 1-30). Vol. 1. https://www.anpocs.com/index.php/encontros/papers/41-encontro-anual-da-anpocs

Coligação Lula Presidente (2002). Vida Digna no Campo: Programa de Governo 2002 Coligação Lula Presidente. São Paulo: Coligação Lula Presidente.

Delgado, G. C. (2010). Especialização primária como limite ao desenvolvimento. Desenvolvimento em Debate, 1 (2), 111-125.

Delgado, G. C. (2013). Reestruturação da economia do agronegócio: Anos 2000. In J. P. STÉDILE, A questão agrária no Brasil: O debate na década de 2000 (pp. 57-88). São Paulo: Expressão Popular.

DinIZ, E. (2011). O contexto internacional e a retomada do debate sobre desenvolvimento no Brasil contemporâneo (2000-2010). Dados: Revista de Ciências Sociais, 54 (4), 493532.

Dualibi, J. (2003). Sarney cobra ação de Lula contra «fora-da-lei». Folha de São Paulo, 29 de julho.

FERNANDES, B. M. (2013). A reforma agrária que o governo Lula Fez e a que pode ser feita. In E. SADER (Org.), Lula e Dilma: 10 anos de governos pós-neoliberais no Brasil (pp. 191-206). São Paulo/Rio de Janeiro: Boitempo/FLACSO Brasil.

FleXor, G. \& Leite, S. P. (2017). Land Market and Land Grabbing in Brazil during the Commodity Boom of the 2000s. Contexto Internacional, 39 (2), 393-420.

Hobsbawm, E. J. (1983). Da Revolução Industrial Inglesa ao Imperialismo. $3^{\mathrm{a}} \mathrm{ed}$. Rio de Janeiro: Forense Universitária.

IgLESIAS, E. (2011). Los movimientos sociales bajo el gobierno de Lula Da Silva: Entre la construcción del proyecto político y la institucionalización del diálogo político. $R e-$ vista SAAP, 5 (1), 131-156. 
LERRER, D. F. \& CARTER, M. (2017). «Consenso de commodities»: Semeando o conservadorismo e des-democratizando o Brasil? In Anais do $41^{\circ}$ Encontro Anual da Anpocs. Caxambu, 23-27 de outubro.

Loera, N. R. (2006). A espiral das ocupações de terra. São Paulo/Campinas: Polis/CeresUnicamp.

MARTINS, J. DE S. (1994). O poder do atraso: Ensaios de sociologia da história lenta. São Paulo: Hucitec.

Martins, J. DE S. (2000). Reforma agrária: O impossível diálogo. São Paulo: Editora da Universidade de Sao Paulo.

Martins, J. DE S. (2011). A política do Brasil: Lúmpen e místico. São Paulo: Contexto. Martins, J. De S. (2016). Do PT das Lutas Sociais ao PT do Poder. São Paulo: Contexto.

Ministério do Desenvolvimento AgráRIo (2003). II Plano Nacional de Reforma Agrária: Paz, Produção e Qualidade de Vida no Meio Rural.

OliveIRA, A. U. (2010). A questão agrária no Brasil: Não reforma e contra reforma agrária no governo Lula. In J. P. DE A. MAGALHÃES et al., Os anos Lula: Contribuições para um balanço crítico 2003-2010 (pp. 287-328). Rio de Janeiro: Garamond.

PahnKe, A. (2018). From Hostile Skepticism to Strategic Utilization: How the Brazilian Landless Movement Learned from Repression to Use Legislation. Social Movement Studies, 17 (2), 175-188.

Painel (2002). Folha de São Paulo, 24 de dezembro. https://www1.folha.uol.com. $\mathrm{br} / \mathrm{fsp} / \mathrm{brasil} / \mathrm{fc} 2412200201 . \mathrm{htm}$

PenNa, C. (2015). Conexões e controvérsias no Incra de Marabá: O Estado como um ator heterogêneo. Rio de Janeiro: Garamond.

Power, T. J. (2014). Continuity in a Changing Brazil:The Transition from Lula to Dilma. In F. DE CAstro, K. Koonings \& M. Wiesebron (Eds.), Brazil Under the Workers' Party (pp. 10-35). London: Palgrave Macmillan.

Ribeiro Neto, C. P. (2018). Formação Política do Agronegócio. Tese de doutorado. Campinas: Universidade Estadual de Campinas.

SAUER, S. \& MÉszÁros, G. (2016). The Political Economy of Land Struggle in Brazil under Workers?: Party Governments. Fournal of Agrarian Change, 17 (2), 397-413.

SECCO, A. (2003). Entrevista: Miguel Rossetto. Veja, pp. 9-13, 26 de março.

SECCO, L. (2011). História do PT, 1978-2010. Cotia: Ateliê.

Sigaud, L. (2005). As condições de possibilidade das ocupações de terra. Tempo Social: Revista de Sociologia da USP, 17 (1), 255-280.

SiLVA, L. I. L. DA (2002). Carta ao Povo Brasileiro. São Paulo, 22 de junho. https:// fpabramo.org.br/wp-content/uploads/2010/02/cartaaopovobrasileiro.pdf

SiLVEIRA, W. (2003). Uso de arma contra MST divide ministros de Lula. Folha de São Paulo, 5 de julho. 
SINGER, A. (2012). Os sentidos do lulismo: Reforma gradual e pacto conservador. São Paulo: Companhia das Letras.

Suwwan, L. (2003). Nova onda de invasões preocupa, diz Lula. Folha de São Paulo, 24 de junho.

Tilly, C. (1978). From Mobilization to Revolution. New York: Random House.

VEIGA, J. E. DA (1991). O desenvolvimento agrícola: uma visão histórica. São Paulo: HUCITEC.

VEIGA, J. E. DA (1994). Fundamentos do agrorreformismo. In J. P. STÉDILE (Org.), A questão agrária hoje (pp. 68-93). $2^{\mathrm{a}}$ ed. Porto Alegre: Universidade Federal do Rio Grande do Sul.

Vianna, L. W. (2007). O Estado novo do PT. Politica Democrática: Revista de política e cultura, $\mathrm{V}$ (18), 45-53. 